\title{
Reseachthevalueof the Type B Natriuretic Peptide (Nt-Probnp) In the Treatment of Heart Failure in Children
}

\author{
Vinh NA ${ }^{1 *}$, Hong $\mathrm{TTM}^{1}$, Ngo Anh Vinh \\ Emergency Department of National Children's Hospital, Viet Nam
}

\begin{abstract}
Measurement of the type B Natriuretic peptide(NT-ProBNP) has become a potent diagnostic aid as a means of identifying patients with heart failure.Thefore, we conducted a study assess the effects of NT-proBNPguided therapy of children with heart failure.

Objective: To study the value of the type B Natriuretic peptide (NT-proBNP) in treatment of heart failure in children.

Study method: A prospectivecase-control study was carried out. Study patients: 100 children were diagnosed with heart failure and they were also classified into different degrees of heart failure according to modified Ross Heart Failure Classification. The control group had 100 patients without cardiovascular disease. Quantitative serum NT-proBNP concentrations and cardiac ultrasound data were analyzedbefore and after treatment and compared between the treatment group and the control group.

Results: NT-proBNP concentration in a disease group $(H F)$ was $1125.26 \pm 1823.40 \mathrm{pg} / \mathrm{ml}$. The concentration level in the control group was $26.74 \pm 38.79 \mathrm{pg} / \mathrm{ml}$. The difference between the two groups is statistically significant $(p<0.01)$. NT- ProBNP concentrations decrease with the state to improve the level of heart failure after treatmnet.

Conclusion: NT-proBNP is valuable to assess the outcomes oftreatmentfor children with heart failure.

Keyword: NT-ProBNP, heart failure, children
\end{abstract}

\section{Introduction}

Heart failure is a common disease in children which causes many serious complications, even death, without early diagnosis and on-time treatment. Diagnosis of heart failure relies on clinical symptoms in children but clinical signs are often difficult to diagnose. Currently, NT-proBNP quantitative serum has been widely adopted and is useful in diagnosing heart failure in countries around the world. However, the treatment and prognosis of heart failure in children in Viet nam was very difficult. To assess the outcomes of treatment for children with heart failure, we proceed with the targeted theme: "A study of the role of Natriuretic type B peptide (NT-proBNP) serum in the treatmentfor childrenwith heart failure".

\section{Patients and Methods}

1. Patients : A treatment group of 100 pediatric patients with heart failure are diagnosed and classified according to the modified Ross Heart Failure Classification, and a control group of 100 children without cardiovascular disease of the same age and sex as the sick children at the National Children's Hospital from April 2014 to June 2016. Quantitative NT-proBNP serum concentrations and echocardiographic parameters of the stady group were assessed before and after treatment and compared to controls.

2. Study method: A prospective case-control study was carried out.

1. General characteristics of the study group

III. Result

1.1. Sex:

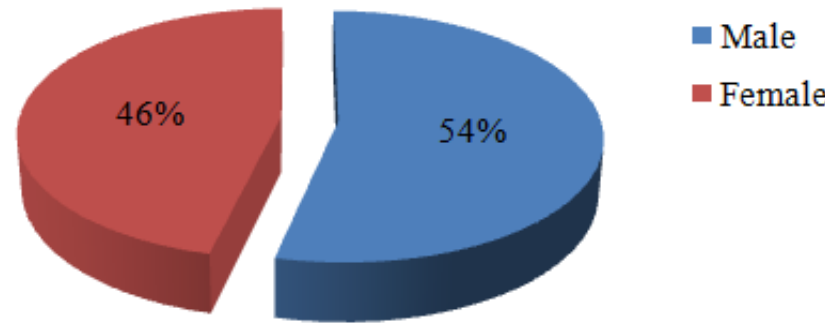

Graph 1. Distribution of patients by sex 
1.2. Age:

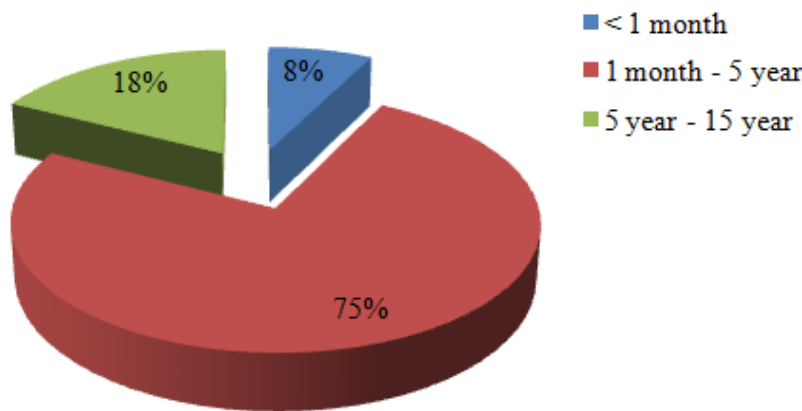

Comment:

Graph 2. The distribution of patients by age

- Ages disease encountered most 1 months - 5 years old.

- Average age: 45,32 $\pm 26,37$ months

2. The clinical symptoms of heart failure (before - after treatment)

\begin{tabular}{|l|l|l|l|l|l|}
\hline \multirow{2}{*}{ Symptoms } & Before & After & \multirow{2}{*}{ p } \\
\cline { 2 - 5 } & $\mathbf{n}$ & $\%$ & $\mathbf{n}$ & $\%$ & \\
\hline Tachypnea & 90 & $90 \%$ & 21 & $21 \%$ & $<0,05$ \\
\hline Tachycardia & 87 & $87 \%$ & 19 & $19 \%$ & $<0,05$ \\
\hline Hepatomegaly & 48 & $48 \%$ & 18 & $18 \%$ & $<0.05$ \\
\hline Sweating & 72 & $72 \%$ & 25 & $25 \%$ & $<0,05$ \\
\hline Edema & 19 & $19 \%$ & 7 & $7 \%$ & $<0,05$ \\
\hline
\end{tabular}

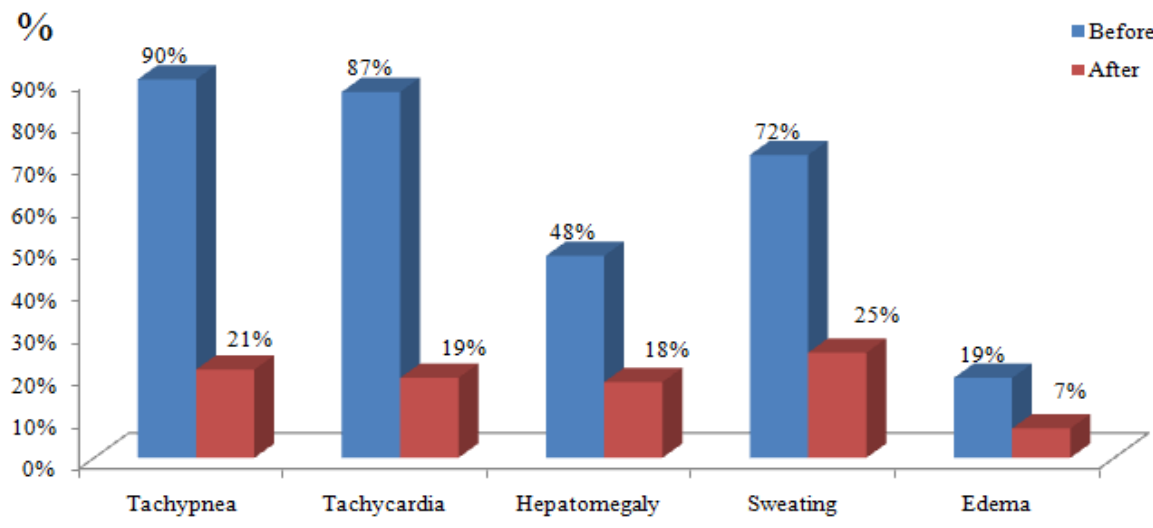

Comment:

The clinical symptoms after treatment have reducedwith statistically significant, $(\mathrm{p}<0.01)$.

3. The echocardiographic parameters in study group

\begin{tabular}{|l|l|l|l|}
\hline \multirow{2}{*}{ Echocardiographic } & Before & After & \multirow{2}{*}{ p } \\
\cline { 2 - 3 } & $\overline{\mathrm{X}}_{ \pm \mathrm{SD}}$ & $\overline{\mathrm{X}}_{ \pm \mathrm{SD}}$ & \\
\hline EF ejection fraction (\%) & $34,2 \pm 2,43 \%$ & $43 \pm 4,78 \%$ & $<0,05$ \\
\hline Index Dd contractile muscle fibers (\%) & $48,5 \pm 5,61 \%$ & $54 \pm 7,32$ & $<0,05$ \\
\hline Pulmonary artery pressure systolic (mmHg) & $36,32 \pm 12,34$ & $25,27 \pm 18,45$ & $<0,05$ \\
\hline
\end{tabular}

-Comment:

Echocardiographic parameters change after treatment with statistically significant, $\mathrm{P}<0,05$.

4. NT-proBNP values in heart failure:

4.1. NT- ProBNPconcentration before and after treatment

\begin{tabular}{|l|l|l|l|}
\hline NT- BNP $(\mathbf{p g} / \mathbf{m g})$ & $\begin{array}{l}\text { Control }^{(1)} \\
(\mathbf{n}=100)\end{array}$ & \multicolumn{2}{|l|}{ Heart failure $(\mathbf{n}=\mathbf{1 0 0})$} \\
\cline { 3 - 4 } & Before $^{(2)}$ & After $^{(3)}$ \\
\hline $\bar{X}_{ \pm}$SD & $26,74 \pm 38,79$ & $1268,26 \pm 1823,40$ & $308,89 \pm 27,40$ \\
\hline $\mathbf{p}$ & & & \\
\hline
\end{tabular}

$\mathbf{p}^{1,2:}$ compare NT-proBNP concentrations between groups of patients before treatment and control group $(\mathbf{p}<0,001)$ 
$\mathbf{p}^{\mathbf{2 , 3} \text { : }}$ compared before and after treatment of heart failure groups: $(\mathbf{p}<0,01)$

$\mathbf{p}^{1,3: N T-p r o B N P}$ comparison of the disease after treatment group and control $(p<0,01)$

\subsection{NT-proBNP concentration on the extent of heart failure}

\begin{tabular}{|l|l|l|l|l|}
\hline \multirow{2}{*}{ Heart failure } & \multicolumn{2}{|l|}{$\begin{array}{l}\text { Before } \\
(\mathbf{n = 8 0})\end{array}$} & \multicolumn{2}{l|}{$\begin{array}{l}\text { After } \\
(\mathbf{n = 3 3})\end{array}$} \\
\cline { 2 - 5 } & $\mathrm{n}$ & $\overline{\mathrm{X}} \pm \mathrm{SD}$ & $\mathrm{n}$ & $\overline{\mathrm{X}} \pm \mathrm{SD}$ \\
\hline Ross I & 22 & $462,91 \pm 390,12$ & 20 & $451,82 \pm 378,16$ \\
\hline Ross II & 28 & $968,26 \pm 732,22$ & 21 & $951,14 \pm 781,35$ \\
\hline Ross III & 23 & $1349,04 \pm 1214,36$ & 20 & $1362,41 \pm 1274,19$ \\
\hline Ross IV & 27 & $1715,09 \pm 1637,23$ & 17 & $1725,11 \pm 1603$ \\
\hline p & & & & \\
\hline
\end{tabular}

p: compare NT-proBNP concentration between the degree of heart failure $(\mathrm{p}<0,05)$

\section{The clinical symptoms of heart failure}

\section{Discussion}

When evaluating the results of treatment, the major clinical symptoms of heart failure significantly reduced after treatment with $\mathrm{p}<0.01$.

The common symptoms in the heart lailure group is the tachypnea and tachycardia, this is the classic symptoms of heart failure. These symptoms have improved after treatment.

\section{The echocardiographic parameters in study group}

An echocardiogram is an important method to assess cardiac function. The main parameters of ultrasound in the evaluation of cardiac function is $\mathrm{EF}$ (left ventricular ejection fraction), \%D (left ventricular contractility index), pulmonarysystolic arterial pressure. When evaluating these parameters to determine the function of the heart change in children with heart failure in the study, the results showed that the EF and $\% \mathrm{D}$ parameters in HF group after treatment increased more before treatment $(p<0.05)$. This proves that children with heart failure function after treatment is improve. Besides evaluating pulmonary systolic artery pressure between the two groups, the results showed that parameters in the heart failure group before treatment were higher than after treatment. It also showed the group of heart failure right ventricular function after treatment was improve. (Table 3)

This result is consistent with results from astudy by YM Law when studied in children [4].

\section{NT-proBNP concentration in heart failure group:}

When comparing NT-proBNP level between two groups of treatment and control,this parameters in before treatment group higher $(1823.40 \pm 1125,26 \mathrm{pg} / \mathrm{ml})$ control group $(26.74 \pm 38.79 \mathrm{pg} / \mathrm{ml})$, the difference is significant with $\mathrm{p}<0.001$. NT-proBNP levelafter treatment groups $(308,89 \pm 27,40)$ were also higher after the control group, $\mathrm{p}<0.05$. When compare before and after heart failuretreatment groups, NT-proBNPlevel before treatment higher $(1823.40 \pm 1125,26 \mathrm{pg} / \mathrm{ml})$ after treatment $(308,89 \pm 27,40 \mathrm{pg} / \mathrm{ml})$ with $\mathrm{p}<0,05$. (Table 4.1).This suggests that NT-proBNP level increased in heart failure and this parameter have diagnostic value in children with heart failure. This result is consistent with a study byThang Pham and colleagues on the research parameters in heart failure in adults [1].

\section{The degree of heart failure after treatment}

- The degree ofheart failure after treatment has decreased when compared before treatment. Classified according to the modified Ross Heart Failure Classification, Level I: control group (without heart failure), Lavel II (mild heart failure), Level III (medium HF), level IV (severe HF).

Before treatment there were 31 patients with degree IV heart failure(the most serious), but after the treatment there were only 19 . Besides the patients with other degrees of heart failure were also reduce after treatment The study results also showed that all 22 patients following heart failure treatment (Before treatment, 100 patients with heart failure, after treatment for 78 patients with heart failure)(Table 4.2). This result is consistent with a studyJohn Gand colleagues on the research for treatment in heart failure [4].

- NT-pro BNP increased with the severity of heart failure:. Nếu NT-pro BN pcàngcaothìmúrcđộsuytimcàngnặng, tiênlượngnặnghơnvàngượclại. VìthếchỉsốNT-ProBNP giúpchobácsỹlâmsàngđánhgiáhiệuquảđiềutrịvàđâycũnglà 1 chỉsốđểxemxétchobệnhnhânraviện hay ngừngđiềutrị.

NT-pro BNP concentration between the degree of heart failure was markedly different and increased with the severity of heart failure from level I to level IV. These parameters increases with the degree of heart failure in clinical practice and the difference between the degree of heart failure is statisticaly significant (Table 4.2). This proves that with increasing levels of heart failure, NT-proBNP concentrations are higher. Therefore 
NT-proBNPis a marker to assessof heart failure the severity of heart failure in children and this is an important role in the assessment of progress and prognosisin heart failure. So NT-proBNP indicator to help clinicians evaluate the effectiveness of treatment.

\section{Conclusion}

- NT-proBNP concentration of children with heart failure is higher than children without heart failure.

- $\quad$ NT-proBNP levels increased with the severity levels of heart failure in clinical practice.

- $\quad$ NT-proBNP concentrations is valuable parameters in follow up treatment and prognosis of heart failure in children.

\section{References}

[1]. PhạmThắng, TạMạnhCưòng, PhanThanhNhung (2010), "Study B-type natriuretic concentrations of plasma peptide of patients with chronic heart failure", Vietnam Medicine, No 1 April 2010, p 51-56.

[2]. 2. Das BB (2010), "Plasma B-type natriuretic peptides in children with cardiovascular diseases", Pediatric Cardiol. 31(8):1135-45.

[3]. Knirsch W, Häusermann E, Fasnacht M (2011), "Plasma B-type natriuretic peptide levels in children with heart disease", ActaPaediatric. 100 (9):1213-6.

[4]. John G, Lainchbury MD, Richard W (2009) "N-Terminal Pro-B-Type Natriuretic Peptide-Guided Treatment for Chronic Heart Failure". J Am CollCardiol. 2009;55(1):53-60

[5]. Law YM, Hoyer AW, Reller MD (2009), "Accuracy of plasma B-type natriuretic peptide to diagnose significant cardiovascular disease in children", J Am CollCardiol. 54(15): 467-75.

[6]. Sugimoto M, Manabe H, Nakau K (2010), "The Role of N-Terminal pro-B-type natriuretic peptide in the diagnosis of congestive heart failure in children. Correlation with the heart failure score and comparison with B-type natriuretic peptide.Circ J, 2010 May, 74(5):998-1005. 